\title{
STUDI SIFAT MEKANIK DARI CAMPURAN BAHAN SERAT TANDAN KELAPA SAWIT DENGAN POLYPROPYLENE DAN POLYSTYRENE PADA PROSES INJECTION MOULDING
}

\author{
Haryston K. Sitepu ${ }^{1}$, Alfian Hamsi ${ }^{2}$, A. Husein Siregar ${ }^{3}$, Mahadi $^{4}$ \\ ${ }^{1,2,3,4}$ Departemen Teknik Mesin, Fakultas Teknik, Universitas Sumatera Utara \\ Email: spawn_aris@yahoo.co.id
}

\begin{abstract}
ABSTRAK
Penggunaan produk dengan bahan baku plastik cukup tinggi, dimana dapat dilihat dari banyaknya produk yang dijual di pasaran dengan berbagai model atau bentuk dan juga harga yang terjangkau. Bahan baku plastik tersebut dapat diolah kembali menjadi berbagai macam bentuk dengan cara mencairkan dan kemudian dicetak dengan proses injection moulding. Untuk mengurangi biaya bahan baku cukup tinggi yang dalam pembuatan produk, maka dilakukan penelitian dengan beberapa alternatif bahan baku. Salah satu alternatif yang dapat digunakan adalah serat tandan kelapa sawit. Salah satu kandungan yang terdapat pada serat tandan kelapa sawit adalah selulosa, dimana selulosa memungkinkan untuk digunakan sebagai campuran bahan baku dalam pembuatan produk dengan bahan plastik. Proses pencetakan menggunakan serat tandan kelapa sawit, polypropylene $(P P)$, polystyrene (PS). Campuran bahan baku ini akan dicetak melalui proses injection moulding dan selanjutnya dilakukan proses uji tarik sehingga dapat diketahui sifat kekuatan mekanik dari spesimen tersebut.
\end{abstract}

Kata kunci : Serat tandan kelapa sawit, polypropylene, polystyrene, injection moulding, proses uji tarik

\section{PENDAHULUAN}

Tingginya permintaan pasar terhadap produk berbahan plastik, mengakibatkan banyaknya pabrik pengolahan bijih plastik. Salah satu keunggulan dari produk berbahan plastik adalah dapat dicetak dengan berbagai bentuk dan harga jual produk juga dapat dijangkau seluruh lapisan masyarakat.

Bahan baku polimer ini sebagian diperoleh dari alam dan sebagian lagi diperoleh dari hasil pengolahan dan penelitian. Polypropylene, polystyrene dan polyethylene merupakan jenis plastik yang dapat didaur ulang dengan melakukan proses pemanasan ulang.

Salah satu penelitian dengan menggunakan campuran bahan polypropylene, polystyrene dan polyethylene menunjukkan bahwa semakin tinggi temperatur pemanasan yang digunakan dalam proses pencetakan maka tegangan maksimum juga semakin akan tinggi [1].

Sumatera utara merupakan salah satu derah penghasil sawit terbesar di Indonesia. Hal ini dapat dilihat dari banyaknya perusahaan pengelola perkebunan kelapa sawit yang tersebar di beberapa daerah. Hasil dari pengolahan kelapa sawit ini adalah CPO, Kernel, Cangkang dan Serat. Serat digunakan sebagai alternatif bahan bakar pada pembangkit boiler. Selain itu, juga dapat dimanfaatkan sebagai campuran bahan baku dalam proses pengolahan bijih plastik. Selulosa yang terkandung dalam limbah kelapa sawit memungkinkan kelapa sawit dapat digunakan sebagai bahan baku produk-produk serat [2].

Sebagai alternatif bahan baku produk plastik maka dilakukan penelitian terhadap serat tandan kelapa sawit. Serat tandan kelapa sawit ini akan dicampurkan dengan bahan baku polypropylene dan polystyrene. Serat tandan kelapa sawit ini akan berfungsi sebagai penguat sedangkan untuk bahan polypropylene dan polystyrene digunakan sebagai pengikat. Salah satu sifat dari polypropylene adalah bisa menjadi liat serta fleksibel, bahkan di suhu rendah melalui penggabungan partikel [3].

Campuran dari ketiga bahan tersebut akan dicetak dengan menggunakan proses injection moulding dan selanjutnya akan dilakukan proses pengujian kekuatan tarik untuk mengetahui kemampuan maksimum campuran dari bahan tersebut dalam menahan beban. 
Proses injection moulding merupakan metode pembentukan material termoplastik dimana material yang meleleh karena pemanasan diinjeksikan ke dalam cetakan yang didinginkan oleh air sehingga mengeras.

Dengan adanya penelitian ini maka diharapkan ketergantungan terhadap bahan baku polimer dapat digantikan dengan penggunaan serat tandan kelapa sawit ini. Selain itu serat tandan kelapa sawit tidak lagi dikategorikan sebagai salah satu limbah yang tidak dapat dimanfaatkan.

\section{METODE PENELITIAN}

Dalam proses penelitian ini akan menggunakan campuran bahan baku yang terdiri dari serat tandan kelapa sawit, polypropylene dan polystyrene.

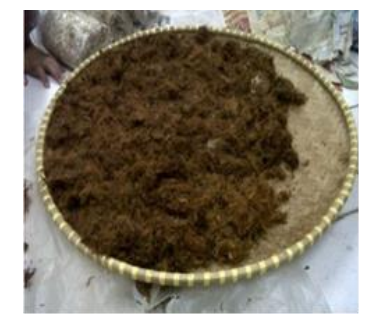

Gambar 1. Serat Tandan

Kelapa Sawit

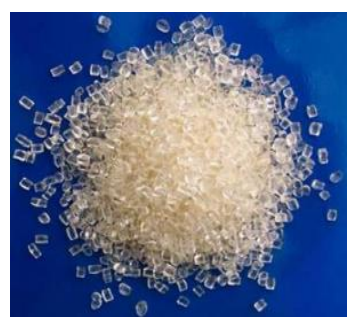

Gambar 2. Polypropylene

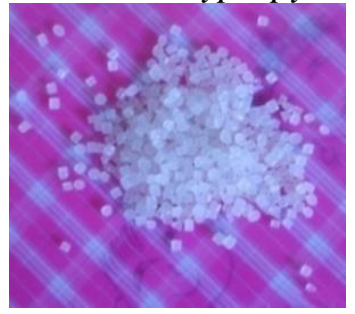

Gambar 3. Polystyrene

\section{Pengolahan Serat Tandan Kelapa Sawit}

Dalam penggunaan serat tandan kelapa sawit sebagai salah satu campuran bahan baku sebaiknya dilakukan pengolahan terlebih dahulu. Pengolahan ini dilakukan karena disebabkan tingginya kandungan zat ekstraktif dan lemak sehingga akan menurunkan kekuatan mekanik dari serat kelapa sawit tersebut. Untuk itu sebaiknya serat tandan kelapa sawit tersebut direndam terlebih dahulu dalam larutan $\mathrm{NaOH} 0,4 \%$ selama 24 jam untuk mengurangi kandungan zat ekstraktif dan lemak tersebut. Setelah itu dilakukan proses pencucian serat tandan kelapa sawit dengan menggunakan air sebelum dikeringkan pada suhu kamar selama 72 jam [5]. Tujuan dari proses pengeringan adalah untuk mengurangi kandungan kadar air pada serat tandan kelapa sawit tersebut.

Setelah proses pengolahan serat tandan kelapa sawit dilakukan, maka selanjutnya dilakukan proses pemotongan serat tendan kelapa sawit menjadi ukuran yang lebih kecil yaitu sekitar 5-7 mm.

\section{Komposisi Bahan Baku}


Setelah proses pemotongan serat tandan kelapa sawit, selanjutnya dilakukan proses penimbangan bahan baku yang akan digunakan. Proses penimbangan menggunakan timbangan digital sehingga nilai berat bahan baku yang diperoleh lebih tepat.

Untuk dapat menghasilkan 1 (satu) buah spesimen dengan menggunakan proses injection moulding akan membutuhkan total berat bahan baku sebanyak 9,5 gram. Komposisi dari berat bahan baku yang akan digunakan tersebut sesuai pada Tabel 1 di bawah ini.

Tabel 1. Komposisi berat bahan baku

\begin{tabular}{|c|c|c|c|c|}
\hline No. & Bahan Baku & Formula l & Formula 2 & Formula 3 \\
\hline 1. & Serat Kelapa Sarit & $1.5 \mathrm{gr}$ & $2 \mathrm{gr}$ & $2.5 \mathrm{gr}$ \\
\hline 2. & Polypropylene (PP) & $4.5 \mathrm{gr}$ & $5 \mathrm{gr}$ & $5.5 \mathrm{gr}$ \\
\hline 3. & Polystryene (PS) & $3.5 \mathrm{gr}$ & $2.5 \mathrm{gr}$ & $1.5 \mathrm{gr}$ \\
\hline \multicolumn{2}{|c|}{ TOTAL } & $9.5 \mathrm{gr}$ & $9.5 \mathrm{gr}$ & $9.5 \mathrm{gr}$ \\
\hline
\end{tabular}

Proses penelitian ini akan menggunakan 3 (tiga) formula dengan komposisi campuran bahan baku yang berbeda-beda setiap formula.

Untuk setiap formula, akan dilakukan pencetakan spesimen sebanyak 3 buah spesimen. Sehingga total campuran bahan baku yang disediakan sebanyak 9 spesimen.

Setelah proses penimbangan bahan baku, selanjutnya dilakukan proses mixing (pencampuran). Proses ini menggunakan mixer sehingga campuran antara ketiga bahan baku yang digunakan dapat lebih merata.

\section{Proses Injection Moulding}

Setelah itu, maka selanjutnya dilakukan proses pencetakan (injection moulding) untuk 9 spesimen tersebut. Pada proses pencetakan ini akan menggunakan Injection Moulding Machine type RN. 350.

Proses injection moulding akan menggunakan 3 variasi temperatur, dimana untuk formula 1 akan menggunakan temperatur $160^{\circ} \mathrm{C}$, formula 2 akan menggunakan temperatur $180^{\circ} \mathrm{C}$ dan formula 3 akan menggunakan temperatur $200^{\circ} \mathrm{C}$.

Bahan baku yang telah tercampur tersebut, selanjutnya dimasukkan ke dalam hopper. Di dalam hopper terdapat Heater (pemanas) yang berfungsi untuk memanaskan bahan baku sehingga akan mencair. Temperatur pemanasan pada heater akan disesuaikan dengan variasi temperatur yang digunakan yaitu $160^{\circ} \mathrm{C}, 180^{\circ} \mathrm{C}$ dan $200^{\circ} \mathrm{C}$.

Setelah bahan baku tersebut mencair, maka selanjutnya bahan baku akan diinjeksikan ke dalam cetakan melalui nozzle yang terdapat pada ujung hopper. Bahan baku tersebut akan terdorong dengan menggunakan bantuan piston.

Setelah proses injeksi dilakukan, maka cetakan akan didinginkan beberapa saat sehingga bahan baku yang telah diinjeksikan tersebut akan mengeras.

Selanjutnya dilakukan proses pengisian ulang hopper dengan bahan baku yang baru sampai tercetak 9 spesimen dengan variasi formula dan temperatur. 


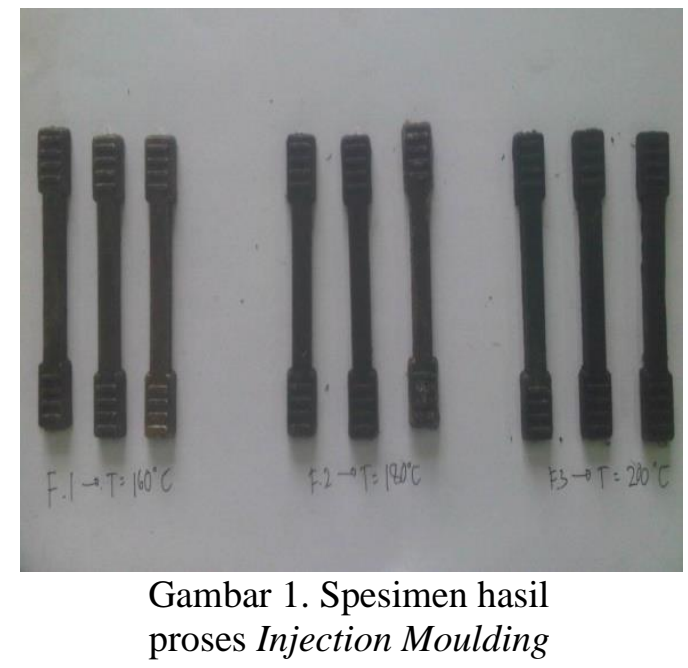

\section{Proses Uji Tarik}

Setelah proses injection moulding selesai dilakukan, maka tahap selanjutnya akan dilakukan proses uji kekuatan tarik terhadap spesimen tersebut. Proses pengujian kekuatan tarik ini bertujuan untuk mengetahui nilai tegangan maksimum dari spesimen dengan menggunakan campuran bahan baku diatas. Proses pengujian kekuatan tarik terhadap spesimen tersebut akan menggunakan Universal Tensile Strength Machine.

Terlebih dahulu dilakukan pengukuran terhadap spesimen sebelum dilakukan proses pengujian, sehingga dapat diketahui perubahan yang terjadi pada spesimen. Setelah itu, selanjutnya dilakukan proses pengujian kekuatan tarik terhadap spesimen.

Proses pengujian ini akan dilakukan dengan memberikan gaya tarik yang berlawanan arah pada salah satu ujung spesimen. Proses pengujian ini akan dilakukan sampai spesimen tersebut menjadi patah. Proses pengujian ini akan mengakibatkan terjadinya perubahan bentuk (deformasi) dari spesimen yang diuji tersebut. Salah satu perubahan yang terjadi antara lain pertambahan panjang dari spesimen tersebut.

Setelah proses pengujian selesai dilakukan, maka tahap selanjutnya akan dilakukan pengukuran akhir terhadap spesimen sehingga dapat diketahui perubahan spesimen tersebut.

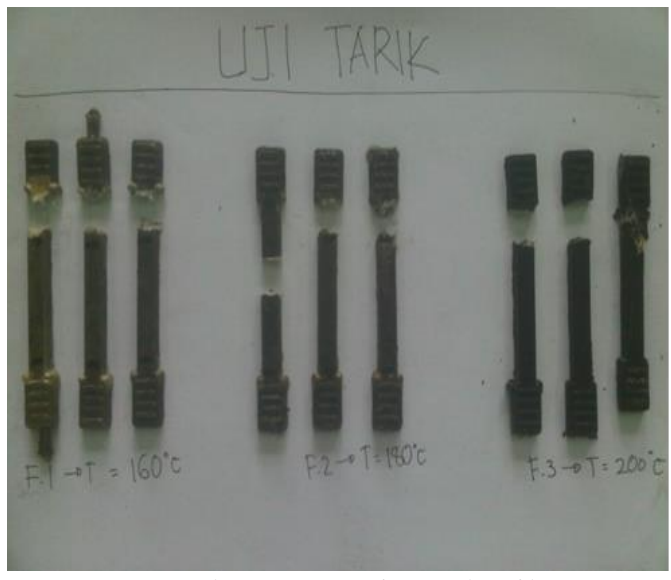

Gambar 2. Spesimen hasil proses Uji Tarik

\section{HASIL DAN DISKUSI}

Setelah dilakukan pengujian kekuatan tarik maka akan diperoleh sifat dan nilai tegangan maksimum dari masing-masing spesimen tersebut. Hasil yang diperoleh dari pengujian spesimen ini dapat digunakan sebagai dasar penggunaan serat tandan kelapa sawit sebagai salah satu campuran bahan dalam pembuatan produk berbahan plastik. 
Berdasarkan hasil penelitian, ada beberapa sifat yang diperoleh dari spesimen antara lain spesimen bersifat elastis-plastis, pada spesimen tidak terdapat lubang dan spesimen tidak langsung putus tetapi spesimen membentuk serat. Dengan adanya serat yang terbentuk maka umur pemakaian dari produk dapat lebih lama.

Berikut ini merupakan tabel hasil pengujian kekuatan tarik dari setiap spesimen.

Tabel 2. Sifat Mekanis Spesimen

\begin{tabular}{|c|c|c|c|c|c|c|}
\hline No. & $\begin{array}{l}\text { Kode } \\
\text { Spesimen }\end{array}$ & $\underset{\left(\mathrm{mm}^{2}\right)}{\mathrm{A}}$ & $\begin{array}{c}\sigma \mathrm{y} \\
\left(\mathrm{N} / \mathrm{mm}^{2}\right)\end{array}$ & $\begin{array}{c}\sigma \mathrm{u} \\
\left(\mathrm{N} / \mathrm{mm}^{2}\right)\end{array}$ & $\begin{array}{c}\varepsilon \\
(\%)\end{array}$ & $\underset{\left(\mathrm{N} / \mathrm{mm}^{2}\right)}{\mathrm{E}}$ \\
\hline 1. & $160-A$ & 50.65 & 6.91 & 9.87 & 5.40 & 182.78 \\
\hline 2. & $160-B$ & 50.96 & 6.87 & 9.81 & 1.10 & 891.82 \\
\hline 3. & $160-C$ & 51.13 & 6.85 & 10.76 & 1.69 & 636.67 \\
\hline 4. & $180-A$ & 51.94 & 4.81 & 7.70 & 2.38 & 323.53 \\
\hline 5. & 180 - B & 50.87 & 4.91 & 7.86 & 0.96 & 818.75 \\
\hline 6. & $180-C$ & 50.54 & 4.95 & 6.93 & 1.14 & 607.89 \\
\hline 7. & $200-A$ & 50.92 & 4.91 & 6.87 & 13.07 & 52.56 \\
\hline 8. & $200-B$ & 50.09 & 3.99 & 4.99 & 13.13 & 38.005 \\
\hline 9. & $200-\mathrm{C}$ & 51.84 & 2.89 & 3.86 & 15.51 & 24.89 \\
\hline
\end{tabular}

Spesimen dengan kode 160-A, 160-B dan 160-C merupakan spesimen dengan temperatur $160^{\circ} \mathrm{C}$. Selanjutnya spesimen dengan kode 180-A, 180-B dan 180-C merupakan spesimen dengan temperatur $180^{\circ} \mathrm{C}$. Dan spesimen dengan kode 200-A, 200-B dan 200-C merupakan spesimen dengan temperatur $200^{\circ} \mathrm{C}$.

Dari hasil tabel diatas, dapat diketahui bahwa nilai tegangan maksimum terbesar adalah spesimen $160-\mathrm{C}$ dengan nilai $\sigma_{\mathrm{U}}$ adalah $10,76 \mathrm{~N} / \mathrm{mm}^{2}$ sedangkan nilai tegangan maksimum terendah adalah spesimen 200-C dengan nilai $\sigma_{U}$ adalah $3,86 \mathrm{~N} / \mathrm{mm}^{2}$. Berdasarkan hasil tabel diatas, dapat diketahui bahwa nilai tegangan tarik maksimum dari setiap spesimen akan menurun jika temperatur pemanasan pada proses injection moulding dinaikkan.

\section{KESIMPULAN}

Dari hasil penelitian spesimen, dapat ditarik kesimpulan antara lain:

1. Spesimen pada temperatur $160^{\circ} \mathrm{C}$ menghasilkan kekuatan yang lebih besar dibandingkan spesimen pada temperatur $180^{\circ} \mathrm{C}$ dan $200^{\circ} \mathrm{C}$, dimana nilai rata-rata tegangan maksimumnya yaitu $10.15 \mathrm{~N} / \mathrm{mm}^{2}$;

2. Faktor-faktor yang mempengaruhi nilai kekuatan spesimen dengan bahan baku campuran, antara lain:

a. Ukuran panjang serat tandan kelapa sawit yang digunakan.

b. Perbandingan komposisi dari berat bahan baku yang digunakan.

3. Sifat fisik dari spesimen antara lain bersifat elastis-plastis, sedikit terdapat lubang karena bahan baku homogen, dan ketika diberikan gaya berlawan tidak langsung putus tetapi membentuk serat;

4. Bahan serat tandan kelapa sawit pada bahan baku yang digunakan tidak dapat mengisi secara merata mall atau cetakan spesimen pada waktu dilakukan proses injection moulding. Hal ini disebabkan karena serat tandan kelapa sawit tersebut terbawa oleh bahan polypropylene dan polystyrene yang telah meleleh sehingga serat kebanyakan mengisi salah satu ujung spesimen. 


\section{DAFTAR PUSTAKA}

[1] Bambang, Eko; 2011. "Pengaruh Variasi Temperatur Pada Proses Plastic Injection Moulding RN. 350 Dengan Bahan Baku Polypropylene Murni, Campuran Polypropylene, Polyethylene dan Polystyrene". Fakultas Teknik USU, Medan.

Situs:

http://repository.usu.ac.id/handle/123456789/26213

[2] Sutardi, T; 1980. "Landasan Ilmu Nutrisi Departemen Ilmu Nutrisi dan Makanan Ternak". Fakultas Peternakan IPB, Bogor.

[3] Hadi, Syamsul; 1995. "Teknologi Bahan 3", Jakarta: Pusat Pengembangan Politeknik

[4] Subiyanto, Bambang, dkk., , "Pemanfaatan Limbah Tandan Kosong dari Industri Pengolahan Kelapa Sawit untuk Papan Partikel dengan Perekat Penol Formaldehida, Jurnal Proquest USU, 2003 